\title{
Kontrol Pendingin Ruangan (Fan) dengan Logika Fuzzy Menggunakan Atmega 8535, LM35 Dan PIR
}

\author{
Sumardi Sadi ${ }^{1}$, Teguh Budiawan ${ }^{2}$ \\ ${ }^{1,2}$ Program Studi Teknik Elektro, Fakultas Teknik, Universitas Muhammadiyah Tangerang \\ Jl. Perintis Kemerdekaan I/33, Cikokol, Kota Tangerang \\ mardiesadi99@gmail.com
}

\begin{abstract}
Abstrak - Penggunaan alat pendingin ruangan semakin meningkat saat ini, hal ini dikarenakan pemanasan global yang terjadi. Untuk mengefesiensi penggunaan alat ini, diperlukan sebuah alat kontrol yang bisa mengendalikan pendingin udara secara otomatis yang menyesuaikan tinggi rendahnya suhu yang dikeluarkan berdasarkan suhu udara dan kegiatan manusia pada suatu ruangan. Penelitian ini akan menggunakan mikrokontroler ATmega 8535 dan terdapat 2 (dua) jenis sensor yaitu LM35 sebagai sensor suhu dan PIR sebagai sensor gerak manusia. Penulis menggunakan metode fuzzy logic dalam penyelesaian masalah khususnya untuk mengambil keputusan yang akan diproses oleh mikrokontroler. Hasil yang diinginkan dalam penelitian ini adalah terciptanya sebuah alat simulasi pendingin ruangan yang dapat mendeteksi suhu dalam sebuah ruangan dan mendeteksi keberadaan manusia. Berdasarkan hasil menunjukkan bahwa alat ini bekerja sesuai dengan rancangannya, dimana jika tak ada gerakan manusia dan suhu $\leq 29{ }^{\circ} \mathrm{C}$ maka motor DC (FAN) akan berhenti tampilan pada LCD “OFF”, jika ada gerakan manusia dan suhu $\geq 30{ }^{\circ} \mathrm{C}$ maka kecepatan motor DC (FAN) akan tampil pada LCD "SLOW", jika ada gerakan manusia dan suhu $\geq 35^{\circ}$ C maka kecepatan motor DC (FAN) akan tampil pada LCD "MEDIUM", jika ada gerakan manusia dan suhu $\geq 40{ }^{\circ} \mathrm{C}$ maka kecepatan motor DC (FAN) akan tampil pada LCD "FAST".
\end{abstract}

Kata kunci: Suhu, Ruangan, Sensor LM35, PIR, Mikrokontroler ATMega8535, Fuzzy Logic

\section{Pendahuluan}

Seiring perkembangan teknologi dan ilmu pengetahuan yang semakin pesat, tingkat kesibukan manusia pun semakin meningkat. Oleh karena itu, manusia sangat membutuhkan suatu alat yang dapat membantu kegiatan manusia. Karena dengan tingkat kesibukan yang meningkat terkadang manusia kurang memperhatikan efisisensi pemanfaatan dari peralatan yang digunakannnya. Salah satunya pendingin udara yang sering digunakan dalam kegiatan manusia sehari-hari. Pendingin ruangan semakin meningkat pemakaianya, apalagi dengan kondisi sekarang, pemanasan global yang terjadi. Penggunaan pendingin udara dalam kegiatan manusia saat ini seringkali kurang efisien. Penempatan pendingin udara pada setiap ruangan menimbulkan suatu kegiatan baru lagi untuk menghidupkan dan mematikan pendingin udara setiap kali manusia meninggalkan ruangan tersebut. Dengan kesibukan manusia hal tersebut terkadang dilupakan dan pada akhirnya pendingin udara tetap hidup walaupun tidak ada kegiatan manusia pada ruangan tersebut. Untuk membantu manusia dalam memanfaatkan pendingin udara secara efisien maka penulis membuat suatu pengendali pendingin udara otomatis yang dapat membaca temperatur suhu pada suatu ruangan.

Sementara itu, saat ini penggunaan fuzzy logic juga berkembang pesat. antara lain penerapan fuzzy logic dalam bidang kontrol seperti yang telah dikembangkan oleh para peneliti sebelumnya. Kelebihan dari sistem ini adalah mampu memproses masukan berupa nilai-nilai riil (nyata) ke dalam besaran fuzzy dan mengolahnya menggunakan basis aturan untuk menghasilkan keputusan yang merupakan keluaran sistem fuzzy logic dengan sangat cepat.

TELKA, Vol.2, No.2, November 2016, pp. 94 105

ISSN (e): 2540-9123

ISSN (p): 2502-1982 
Dalam pembuatan alat aplikasi Kontrol Pendingin Ruangan (FAN) Dengan Logika Fuzzy Menggunakan ATmega 8535, LM35 Dan PIR ini terdapat beberapa teori dasar dari komponen alat. Teori-teori dasar dan komponen utama dari alat ini terdiri dari Fuzzy Logic, mikrokontroler ATmega8535, sensor suhu LM35, LCD, PIR (Passive Infrared Receiver) dan Motor DC (FAN).

\section{Tinjauan Pustaka}

\subsection{Fuzzy Logic}

Logika fuzzy (fuzzy logic) adalah suatu cara tepat untuk memetakan suatu ruang input ke dalam suatu ruang output. Teknik ini menggunakan teori matematis himpunan fuzzy. Logika fuzzy berhubungan dengan ketidakpastian yang telah menjadi sifat alamiah manusia. Ide dasar dari logika fuzzy muncul dari prinsip ketidakjelasan. Teori fuzzy pertama kali dibangun dengan menganut prinsip teori himpunan.

Dalam himpunan konvensional (crisp), elemen dari semesta adalah anggota atau bukan anggota dari himpunan. Dengan demikian, keanggotaan dari himpunan adalah tetap. [9]. Salah satu metode dalam logika fuzzy yaitu metode fuzzy mamdani. Metode Fuzzy Mamdani. Metode Mamdani sering juga dikenal dengan nama Metode Max-Min. Metode ini diperkenalkan oleh Ebrahim Mamdani pada tahun 1975.

\subsection{Mikrokontroler ATmega 8535}

Mikrontroller ATmega8535 merupakan mikrokontroller generasi AVR (Alf and Vegard's Risk processor). Mikrokontroller AVR memiliki arsitektur RISC (Reduced Instruction Set Computing) 8 bit, dimana semua instruksi dikemas dalam kode 16-bit (16-bits word) dan sebagian besar instruksi dieksekusi dalam 1 siklus clock.[9]

Mikrokontroler ATmega8535 memiliki arsitektur seperti gambar di bawah ini :

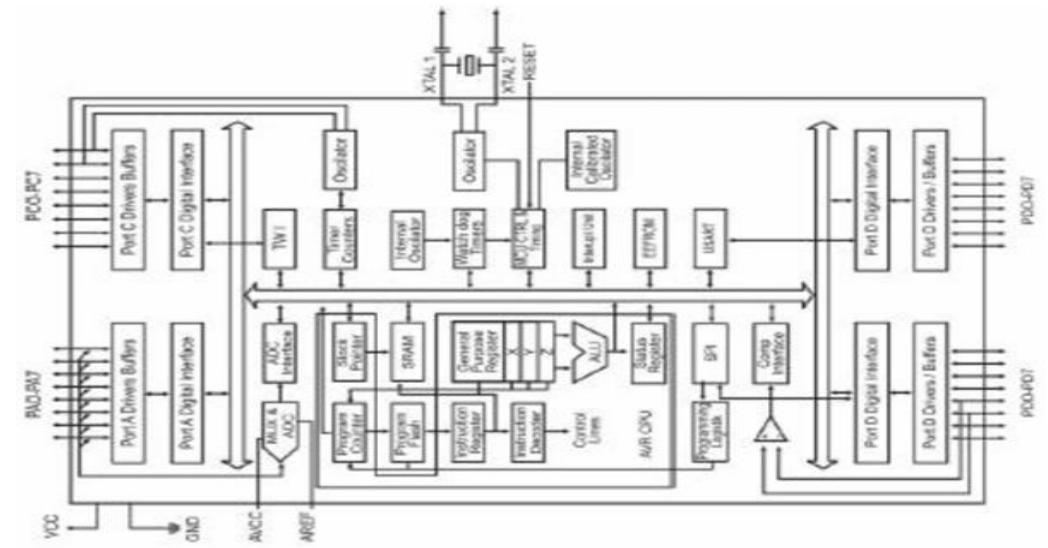

Gambar 1. Diagram Blok Fungsional Atmega8535

(Sumber : Data Sheet Atmel Microcontroller ATmega 8535)

Gambar diatas memperlihatkan bahwa ATmega8535 memiliki bagian sebagai berikut :

1. Saluran I/O sebanyak 32 buah, Port A, Port B, Port C, dan Port D

2. ADC 10 bit sebanyak 8 saluran.

3. Tiga buah Timer/Counter dengan kemampuan perbandingan.

4. CPU yang terdiri dari 3 buah register.

5. Watchdog Timer dengan osilator internal.

6. SRAM sebesar 512 Byte.

7. Memori Flash sebesar $8 \mathrm{~Kb}$ dengan kemmampuan Read While Write.

8. Unit interupsi internal dan eksternal. 
9. Port antarmuka SPI

10. EEPROM (Electrically Erasable Programmable Read Only Memory) sebesar 512 Byte yang dapat deprogram saat operasi.

11. Antarmuka Komparator analog.

12. Port USART untuk komunikasi serial dengan kecepatan maksimal 2,5 Mbps.

13. Sistem mikroprosesor 8 bit berbasis RISC dengan kecepatan maksimal $16 \mathrm{Mhz}$.

\subsection{Sensor Suhu LM 35}

Sensor LM35 adalah komponen elektronika yang memiliki fungsi untuk mengubah besaran suhu menjadi besaran listrik dalam bentuk tegangan. Untuk komponen sensor suhu, parameter yang harus dipertimbangkan dan ditangani dengan baik karena hal ini dapat menyebabkan kesalahan pengukuran.[6]

Seperti sensor suhu jenis RTD PT100 atau PT1000 misalnya, komponen ini tidak boleh dieksitasi oleh arus melebihi 1 miliampere, jika melebihi, maka sensor akan mengalami selfheating yang menyebabkan hasil pengukuran senantiasa lebih tinggi dibandingkan suhu yang sebenarnya. Berikut ini adalah spesifikasi dari sensor LM35 :

1. Dapat dikalibrasi langsung ke dalam besaran Celcius.

2. Faktor skala linier $+10 \mathrm{mV} /{ }^{\circ} \mathrm{C}$.

3. Tingkat akurasi $0,5^{\circ} \mathrm{C}$ saat suhu kamar $\left(25^{\circ} \mathrm{C}\right)$.

4. Jangkauan suhu antara $-55^{\circ} \mathrm{C}$ sampai $150^{\circ} \mathrm{C}$.

5. Tegangan masukan 4 Volt hingga 30 Volt.

6. Kerja kurang dari $60 \mu \mathrm{A}$.

7. Impedansi keluaran rendah $0,1 \Omega$ untuk beban $1 \mathrm{~mA}$.

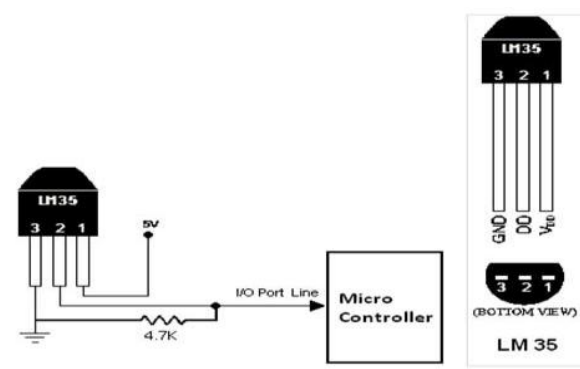

Gambar 2. Struktur Sensor Suhu LM35

(Sumber : Data Sheet LM 35)

\subsection{LCD (Liquid Crystal Display)}

Liquid Crystal Display (LCD) dapat dengan mudah dihubungkan dengan mikrokontroller seperti ATMEGA8535. Sesuai standarisasi yang cukup terkenal digunakan banyak vendor LCD, yaitu HD44780, yang memiliki chip kontroler Hitachi 44780. LCD bertipe ini memungkinkan pemrogram untuk mengoperasikan komunikasi data secara 8 bit atau 4 bit. Berikut adalah rangkaian interface LCD dan susunan umum kaki LCD bertipe HD44780 [2].

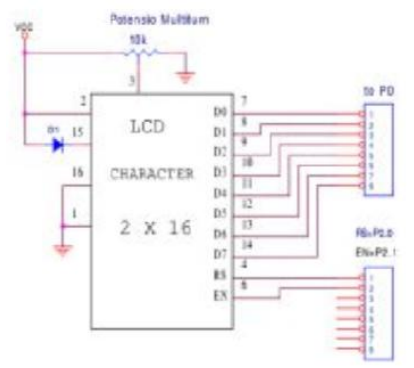

Gambar 3. Skematik Rangkaian Interface LCD

(Sumber : Data Sheet LCD) 
Berdasarkan gambar 3, jika menggunakan jalur data 4 bit akan ada 7 jalur ( 3 untuk jalur kontrol \& 4 untuk jalur data). Jika menggunakan jalur data 8 bit maka akan ada 11 jalur ( 3 untuk jalur kontrol \& 8 untuk jalur data).Tiga jalur kontrol ke LCD ini adalah EN (Enable), RS (Register Select) dan R/W (Read/Write).

Fungsi dari pin LCD 44780 adalah sebagai berikut : GND berfungsi untuk ground, VCC berfungsi untuk sumber tegangan 5 volt. , VEE berfungsi untruk pengaturan kontras, RS berfungsi untuk pemilihan register $(0=$ Register Instruksi dan $1=$ Register Data), R/W berfungsi untuk mode baca/ tulis $(0=$ Mode Tulis dan $1=$ Mode Baca), EN berfungsi untuk enable $(0=$ start to lacht data to LCD character dan 1= disable), DB0 berfungsi untuk LSB/Data 0, DB1 berfungsi untuk Data 1, DB2 berfungsi untuk Data 2, DB3 berfungsi untuk Data 3, DB4 berfungsi untuk Data 4, DB5 berfungsi untuk Data 5, DB6 berfungsi untuk Data 6, DB7 berfungsi untuk MSB/Data 7, BPL berfungsi untuk Back Plane Light.

Berdasarkan fungsi dari PIN LCD 44780 terdapat Jalur EN yang dinamakan Enable. Jalur ini digunakan untuk memberitahu LCD bahwa sedang mengirimkan sebuah data. Untuk mengirimkan data ke LCD, maka melalui program EN harus dibuat logika low "0" dan set pada dua jalur kontrol yang lain RS dan RW. Ketika dua jalur yang lain telah siap, set EN dengan logika "1" dan tunggu untuk sejumlah waktu tertentu (sesuai dengan data sheet dari LCD tersebut) dan berikutnya set EN ke logika low "0" lagi. [6]. Jalur RS adalah jalur Register Select. Ketika RS berlogika low "0", data akan dianggap sebagai sebuah perintah atau instruksi khusus (seperti clear screen, posisi petunjuk, dll). Ketika RS berlogika high "1", data yang dikirim adalah data teks yang akan ditampilkan pada tampilan LCD. Sebagai contoh, untuk menampilkan huruf "T" pada layar LCD maka RS harus diset logika high "1". Jalur R/W adalah jalur kontrol Read/ Write. Ketika R/W berlogika low (0), maka informasi pada bus data akan dituliskan pada layar LCD. Ketika R/W berlogika high "1", maka program akan melakukan pembacaan memori dari LCD. Sedangkan pada aplikasi umum kaki R/W selalu diberi logika low "0”.[6]

\subsection{PIR (Passive Infrared Receiver)}

PIR (Passive Infrared Receiver) merupakan sebuah sensor berbasis infrared. Akan tetapi, tidak seperti sensor infrared kebanyakan yang terdiri dari IR LED dan fototransistor. PIR tidak memancarkan apapun seperti IR LED. Sesuai dengan namanya 'Passive', sensor ini hanya merespon energi dari pancaran sinar inframerah pasif yang dimiliki oleh setiap objek bergerak yang terdeteksi olehnya.

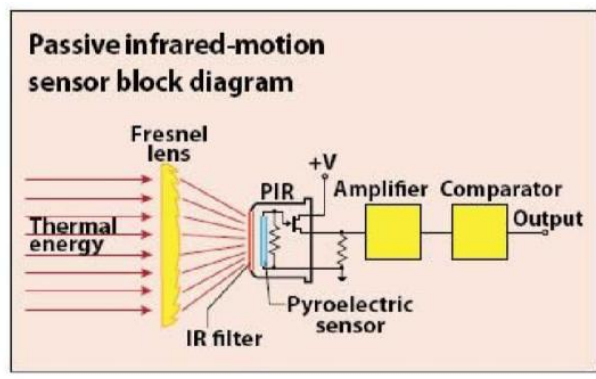

Gambar 4. Rangkaian Sensor PIR (Sumber : Data Sheet PIR)

Pada gambar 4 terdapat rangkaian penyusun sensor PIR yang terdiri dari lensa Fresnel, IR filter, pyroelectric sensor, amplifier, dan comparator. Sensor PIR hanya bereaksi pada tubuh manusia saja disebabkan karena adanya IR Filter yang menyaring panjang gelombang sinar inframerah pasif. IR Filter dimodul sensor PIR ini mampu menyaring panjang gelombang sinar inframerah pasif antara 8 sampai 14 mikrometer, sehingga panjang gelombang yang dihasilkan dari tubuh manusia yang berkisar antara 9 sampai 10 mikrometer ini saja yang dapat dideteksi oleh sensor. Jadi, ketika seseorang berjalan melewati sensor, sensor akan menangkap pancaran sinar inframerah pasif yang dipancarkan oleh tubuh manusia yang memiliki suhu yang berbeda dari lingkungan. 
Pancaran sinar inframerah inilah yang kemudian ditangkap oleh Pyroelectric sensor yang merupakan inti dari sensor PIR ini sehingga menyebabkan Pyroelectic sensor yang terdiri dari galium nitride, caesium nitrat dan litium tantalate menghasilkan arus listrik. Kemudian sebuah sirkuit amplifier yang ada menguatkan arus tersebut yang kemudian dibandingkan oleh komparator sehingga menghasilkan output.[5]

\section{Perancanga Alat}

Dalam pembuatan sebuah alat elektronika yang berbasis mikrokontroler, ada 2 hal penting yang harus diperhatikan yaitu cara kerja alat tersebut dari tahap input hingga output, juga bentuk pemrograman yang ditanamkan ke dalam mikrokontrolernya. Agar alat tersebut dapat bekerja sesuai yang diinginkan, maka terlebih dahulu harus dibuat perancangan alat, yang terdiri dari perancangan perangkat keras dan perangkat lunak atau pemrogramannya.

\subsection{Perancangan Perangkat Keras}

Pembahasan pada perancangan perangkat keras dari kontrol pendingin ruangan ini mencakup 3 bahasan. Pertama, perancangan alur kerja rangkaian yaitu tentang rancangan awal cara kerja alat secara bertahap. Kedua, perancangan rangkaian alat yang membahas seputar bagaimana alat dirancang. Ketiga, perancangan maket alat yang membahas tentang rancangan bentuk jadi alat.

\subsection{Perancangan Alur Kerja}

Alur kerja alat ini dibagi menjadi 4 blok yaitu blok aktivator, blok masukan, blok proses, dan blok keluaran. Gambar 3.1 berikut ini adalah gambar diagram rancangan alur kerja alat, serta penjelasannya.

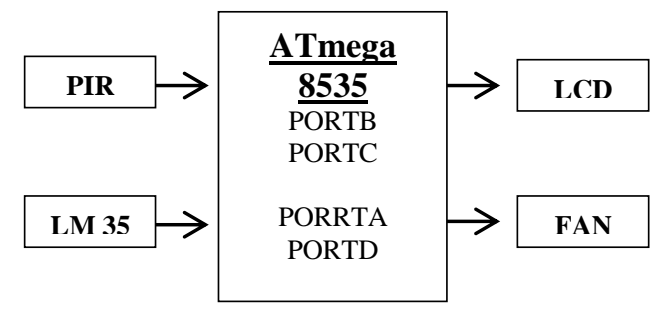

Gambar 5. Diagram Blok Kontrol Pendingin Ruangan (Sumber : Dokumen Pribadi)

Berdasarkan gambar 5 di atas, alur kerja alat dimulai dari blok aktivator. Blok aktivator berfungsi sebagai pengaktif atau pemberi sumber tegangan ke ketiga blok di bawahnya, yaitu blok input/masukan, blok proses, dan blok output/keluaran.

Blok masukan meliputi sensor PIR dan sensor suhu LM35. Input dari alat ini berasal dari pendeteksian ada atau tidaknya keberadaan manusia menggunakan sensor PIR, dan mengukur suhu ruangan yang akan dideteksi oleh sensor suhu LM35. Hasil pendeteksian kedua sensor ini digunakan sebagai masukan ke blok proses.

Blok proses pada alat ini berupa mikrokontroler ATmega8535. Input dari sensor PIR dan sensor suhu LM35 diteruskan ke blok proses, yaitu mikrokontroler ATmega8535 untuk memproses dan menentukan output masing-masing ke Port C.O - C.8 untuk LCD dan Port D.0 D. 2 untuk fan.

Pada blok output, output dari mikrokontroler disalurkan menuju LCD, untuk menampilkan suhu pada ruangan \& keadaan gerak motor DC (FAN).

\subsection{Perancangan Rangkaian Alat}

Setelah membuat rancangan alur kerja alat, maka selanjutnya merancang rangkaian alat sesuai dengan alur kerja alat. Setiap komponen elektronika yang digunakan pada alat ini memiliki 
fungsi yang berbeda-beda, namun saling mendukung satu sama lain. Oleh karena itu, bentuk desain rangkaian alat dibuat agar menjadi kaidah dalam pemasangan komponen-komponen elektronikanya.

Di bawah ini adalah gambar 6 yang menggambarkan rancangan rangkaian alat secara keseluruhan.

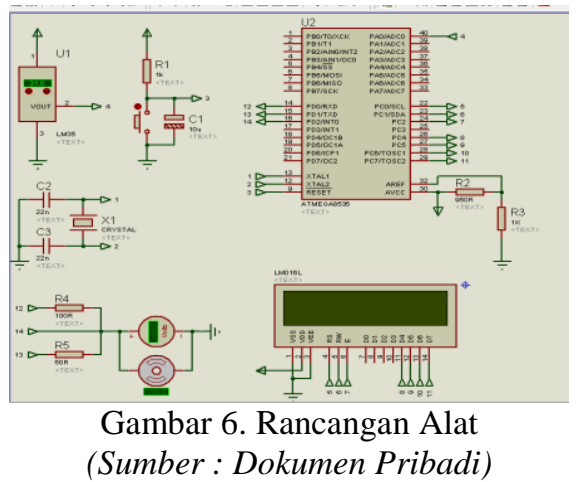

Berdasarkan rancangan alat pada gambar 6 diatas, pemasangan komponen utama dan komponen pendukung pada rangkaian alat akan dijelaskan sebagai berikut :

1. Sebuah resistor \& kapasitor polar dihubungkan ke port Reset ATmega8535. Bagian ini berfungsi sebagai penghapus program yang ditanamkan di ATmega8535 yang diperlukan saat memperbaiki kesalahan dalam pemrograman.

2. 1 XTAL dan 2 kapasitor non polar dihubungkan ke port XTAL.1 \& XTAL.2 ATmega8535. Bagian ini berfungsi sebagai penghasil sumber clock bagi ATmega8535.

3. Output dari sensor suhu LM 35 dihubungkan ke port A.0 ATMEGA8535. Bagian ini memanfaatkan port A yang memiliki fungsi Analog to Digital Converter (ADC) sebagai pengkonversi nilai data suhu dari sensor suhu LM 35 yang berupa sinyal analog, menjadi sinyal digital agar dapat dibaca dan diproses oleh ATmega8535.

4. Liquid Crystal Display (LCD) dihubungkan dengan port C.0 sampai C.7. bagian ini berfungsi sebagai penampil dari program yang telah dibuat.

5. Motor dihubungkan ke port D.0 sampai D.2 bagian ini berfungsi sebagai output dar logika fuzzy.

6. PIR (Passive Infrared Reciever) dihubungkan ke relay berfungsi untuk mengaktifkan/menghubungkan tegangan ke motor DC (FAN).

\subsection{Algoritma Progam}

Untuk mempermudah pembuatan program aplikasi Kontrol Pendingin Ruangan (FAN) Dengan Logika Fuzzy Menggunakan ATmega 8535, LM 35 dan PIR, maka dibuatlah diagram flowchart yang menjelaskan cara kerja alat tahap demi tahap berdasarkan pemograman yang akan dimasukan ke dalamnya. Flowchart program dari alat dapat dilihat pada gambar 7 dibawah ini : 


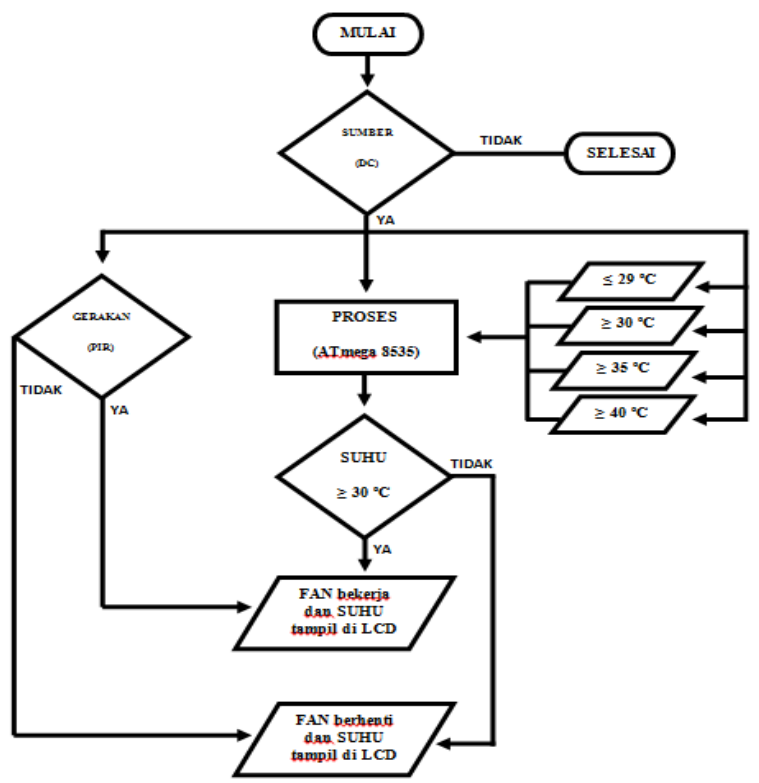

Gambar 7. Flowchart Kontrol Pendingin Ruangan (Sumber : Dokumen Pribadi)

Berdasarkan pada gambar 7, diagram flowchart Kontrol Pendingin Ruangan (FAN) dengan Logika Fuzzy Menggunakan ATmega 8535, LM 35 dan PIR diatas terbagi menjadi beberapa langkah, yaitu:

1. Pertama dimulai dari terminal "START" yang menandakan awal dari program.

2. Kedua yaitu memasuki pilihan "Sumber DC". Apbila ada sumber DC yang terhubung maka program akan berlanjut ke langkah ketiga dan apabila tidak ada sumber yang terhubung maka program berakhir pada terminal "SELESAI".

3. Ketiga yaitu memasuki pada pilihan "Ada Gerakan". Apabila sensor PIR telah mendeteksi gerakan manusia maka FAN akan bekerja ke langkah keempat dan apbila sensor PIR tidak mendeteksi adanya gerakan manusia FAN akan berhenti kemudian akan kembali pada langkah kedua.

4. Keempat yaitu menentukan kondisi suhu pada ruangan dengan logika fuzzy apabila "Temp. $\leq 29^{\circ} \mathrm{C}$ " maka "Motor DC (FAN) berhenti dan tampil di LCD OFF", apabila "Temp. $\geq 30^{\circ} \mathrm{C}$ " maka "Motor DC (FAN) tampil di LCD SLOW", apabila "Temp. $\geq 35$ ${ }^{\circ} \mathrm{C}$ " maka "kecepatan Motor DC (FAN) tampil di LCD MEDIUM", apabila "Temp. $\geq 40$ 'C" maka "kecepatan Motor DC (FAN) tampil di LCD FAST" dan program logika fuzzy akan terus berlanjut.

Berdasarkan pada gambar 7, spesifikasi rancangan program Kontrol Pendingin Ruangan (FAN) dengan Logika Fuzzy Menggunakan ATmega 8535, LM 35 dan PIR dapat dijabarkan pada table 1 berikut ini.

Tabel 1. Spesifikasi Rancangan Program

\begin{tabular}{|l|l|l|}
\hline \multicolumn{1}{|c|}{$\begin{array}{c}\text { Gerakan } \\
\text { Manusia }\end{array}$} & \multicolumn{1}{|c|}{ Suhu } & \multicolumn{1}{c|}{ Tindakan } \\
\hline Ada & Temp. $\leq 29^{\circ} \mathrm{C}$ & Motor (FAN) berhenti \& tampil di LCD OFF \\
\hline Ada & Temp. $\geq 30^{\circ} \mathrm{C}$ & Motor (FAN) bekerja \& kecepatan motor DC (FAN) tampil di LCD SLOW \\
\hline Ada & Temp. $\geq 35^{\circ} \mathrm{C}$ & $\begin{array}{l}\text { Motor (FAN) bekerja \& kecepatan motor DC (FAN) tampil di LCD } \\
\text { MEDIUM }\end{array}$ \\
\hline Ada & Temp. $\geq 40^{\circ} \mathrm{C}$ & Motor (FAN) bekerja \& kecepatan motor DC (FAN) tampil di LCD FAST \\
\hline Tidak ada & Temp. $\leq 29^{\circ} \mathrm{C}$ & Motor DC berhenti \\
\hline Tidak ada & Temp. $\geq 30^{\circ} \mathrm{C}$ & Motor DC berhenti \\
\hline Tidak ada & Temp. $\geq 35^{\circ} \mathrm{C}$ & Motor DC berhenti \\
\hline Tidak ada & Temp. $\geq 40^{\circ} \mathrm{C}$ & Motor DC berhenti \\
\hline
\end{tabular}


Spesifikasi rancangan program diatas menunjukan bahwa ada beberapa kondisi agar motor dc (FAN) bekerja, kondisi 1 dimana ada gerakan dan tempratur $\geq 30{ }^{\circ} \mathrm{C}$ maka motor (FAN) bekerja \& kecepatan motor dc (FAN) tampil di LCD SLOW, kondisi 2 dimana ada gerakan dan tempratur $\geq 35^{\circ} \mathrm{C}$ maka motor dc (FAN) bekerja \& kecepatan motor dc (FAN) tampil di LCD MEDIUM, kondisi 3 dimana ada gerakan dan tempratur $\geq 40{ }^{\circ} \mathrm{C}$ maka motor dc (FAN) bekerja $\&$ kecepatan motor DC (FAN) tampil di LCD FAST.

\subsection{Pembuatan Program}

Pembuatan program dimulai dengan membuat listing program dengan menggunakan bahasa C. Berikut ini adalah program bahasa $\mathrm{C}$ untuk kontrol pendingin ruangan dengan logika fuzzy menggunakan ATmega 8535, LM 35 dan PIR.

Dalam pemrograman ini, hal yang pertama kali dilakukan adalah memanggil library pengarah pre-processor, dalam hal ini pre-processor adalah ATmega8535, serta pemanggilan fungsi pustaka stdio, delay, dan LCD.

\subsection{Pengisian Program}

Untuk menigisi program ke dalam mikrokontroler terlebih dahulu harus dilakukan beberapa langkah seperti pada gambar 8 , berikut ini.

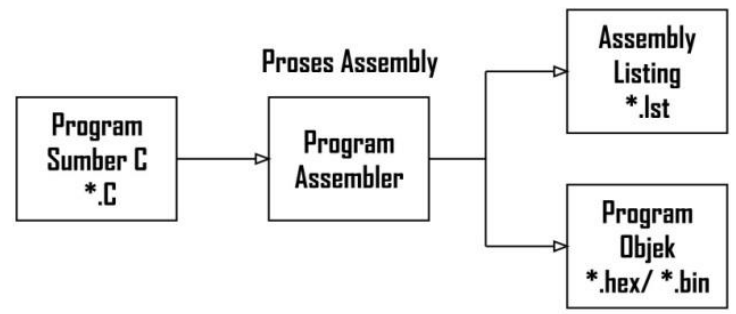

Gambar 8. Blok Proses Downloader

(Sumber : Dokumen Pribadi)

Berdasarkan pada gambar 8, langkah proses downloader dimulai dari mengubah program sumber assembly atau $\mathrm{C}$ menjadi program objek melalui proses assembly terlebih dahulu. Untuk melakukan proses assembly dibutuhkan sebuah program yang disebut program assembler yang berfungsi melakukan konversi ke dalam program objek di mana program objek tersebut dapat berbentuk $H E X$ atau BIN. Selain program objek program assembler juga dapat menghasilkan file listing assembly.[4]

Program objek yang merupakan hasil dari proses assembly dapat didownload ke dalam sistem mikrokontroler menggunakan Programmer ISP melalui ISP Port. Proses pemrograman dapat menggunakan ISP Cable atau DUISP untuk computer yang menggunakan Port USB. Berikut ini adalah gambar 3.6 yaitu konfigurasi dari program kontrol pendingin ruangan (FAN) dengan logika fuzzy menggunakan ATmega 8535, LM 35 dan PIR.

\section{Analisis dan Pembahasan}

Setelah kontrol pendingin ruangan (FAN) dengan logika fuzzy menggunakan ATmega 8535, LM 35 dan PIR dibuat, maka pada bab ini akan dilakukan pembahasan tentang uji coba alat. Pengujian kontrol pendingin ruangan (FAN) dengan logika fuzzy menggunakan ATmega 8535, LM 35 dan PIR terbagi menjadi bebrapa bagian yaitu pengujian deteksi gerakan manusia, pengujian suhu dan pengujian kerja dari LCD.

\subsection{Pengujian Deteksi Gerakan Manusia}

Sensor PIR pendeteksi pada kontrol pendingin ruangan (FAN) dengan logika fuzzy menggunakan ATmega 8535, LM 35 dan PIR ini memiliki kemampuan mendeteksi keberadaan manusia berdasarkan gerakan \& pancaran gelombang infra merah yang berasal dari manusia. 
Pengujian kemampuan sensor PIR ini dimaksudkan untuk mengetahui responsif dari sensor PIR, yang akan merespon gerakan manusia dalam ruangan. Bentuk pengujianya adalah seperti gambar berikut ini.
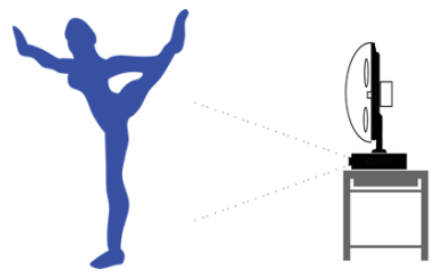

Gambar 9. Pengujian Cara Kerja Sensor PIR (Sumber : Dokumen Pribadi)

Berdasarkan gambar 9, pengujian deteksi gerakan manusia dilakukan dengan melakukan gerakan tangan atau anggota tubuh lainnya di depan sensor pir sebagai inputan dan output dari sensor PIR difungsikan sebagai switcth yang mengaktifkan motor DC (FAN).

\subsection{Pengujian Suhu pada Ruangan}

Pengujian pada suhu pada sensor LM 35 dilakukan dengan memberikan panas degan suhu tertentu dan diukur dengan tegangan output yang dihasilkan. Sensor suhu LM 35 memiliki jangkauan suhu $0^{\circ} \mathrm{C}-150^{\circ} \mathrm{C}$ demgan kenaikan $10 \mathrm{mV}$ untuk setiap derajat celcius. Perubahan tegangan yang dikirim oleh sensor dapat dilihat pada table dibawah ini :

Table 2 Perubahan Tegagan Output Sensor Suhu

\begin{tabular}{|c|c|c|}
\hline \multirow{2}{*}{ Input Suhu (Celcius) } & \multicolumn{2}{|c|}{ Output Tegangan } \\
\cline { 2 - 3 } & $(\mathrm{mV})$ & $(\mathrm{V})$ \\
\hline$\leq 29$ & 290 & 0,29 \\
\hline 30 & 300 & 0,30 \\
\hline 31 & 310 & 0,31 \\
\hline 32 & 320 & 0,32 \\
\hline 33 & 330 & 0,33 \\
\hline 34 & 340 & 0,34 \\
\hline 35 & 350 & 0,35 \\
\hline 36 & 360 & 0,36 \\
\hline 37 & 370 & 0,37 \\
\hline 38 & 380 & 0,38 \\
\hline 39 & 390 & 0,39 \\
\hline 40 & 400 & 0,40 \\
\hline
\end{tabular}

Pengujian kemampuan sensor LM 35 ini dimaksudkan untuk mengetahui respon efektif dari sensor LM 35 saat mendeteksi suhu dari objek. Bentuk pengujiannya adalah seperti gambar berikut ini :

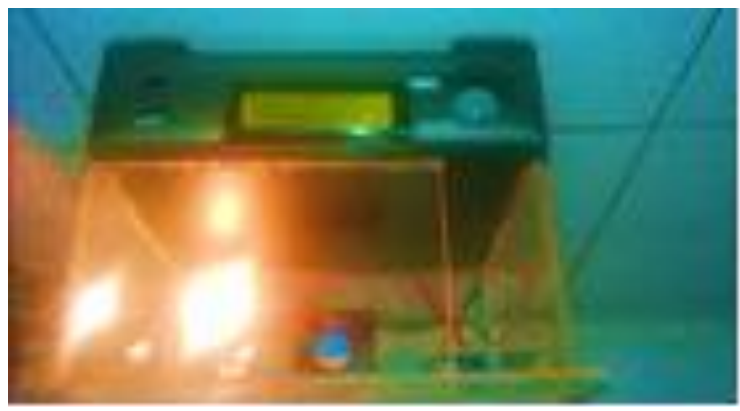

Gambar 10. Pengujian Sensor Suhu LM 35

(Sumber : Dokumen Pribadi) 
Berdasarkan gambar diatas, pengujian deteksi suhu ini hanya akan bekerja apabila sensor suhu mendeteksi sinyal masukan sebesar $30^{\circ} \mathrm{C}-40^{\circ} \mathrm{C}$. Hasil dari pengujianya dapat dilihat pada table berikut ini:

Tabel 3. Perubahan Suhu dan Gerakan Motor DC (FAN)

\begin{tabular}{|l|l|}
\hline Motor DC (FAN) & $\begin{array}{l}\text { Temperatur } \\
\text { Suhu }\left({ }^{\circ} \mathrm{C}\right)\end{array}$ \\
\hline OFF & $\leq 29$ \\
\hline SLOW & 30 \\
\hline SLOW & 31 \\
\hline SLOW & 32 \\
\hline SLOW & 33 \\
\hline SLOW & 34 \\
\hline MEDIUM & 35 \\
\hline MEDIUM & 36 \\
\hline MEDIUM & 37 \\
\hline MEDIUM & 38 \\
\hline MEDIUM & 39 \\
\hline FAST & $\geq 40$ \\
\hline
\end{tabular}

Hasil dari percobaan seperti pada tabel 3 diatas menunjukan bahwa sensor suhu LM 35 mendeteksi suhu pada ruangan yang akan diproses oleh mikrokontrol dan akan mengubah gerakan atau kecepatan putaran motor DC (FAN). Penjelasan mengenai percobaan tersebut adalah sebagai berikut :

1. Jika temperatur suhu $\leq 29^{\circ} \mathrm{C}$ maka motor DC (FAN) berhenti (OFF)

2. Jika temperatur suhu $\geq 30^{\circ} \mathrm{C}$ maka motor DC (FAN) berputar (SLOW)

3. Jika temperatur suhu $\geq 35^{\circ} \mathrm{C}$ maka motor DC (FAN) berputar (MEDIUM)

4. Jika temperatur suhu $\geq 40^{\circ} \mathrm{C}$ maka motor DC (FAN) berputa (FAST)

\subsection{Pengujian Kerja LCD}

LCD pada alat ini berfungsi sebagai penampil suhu yang terdeteksi oleh LM 35 dalam satuan ${ }^{\circ} \mathrm{C}$ dan kondisi putaran atau kecepatan motor DC (FAN). Untuk mengetahui lcd bekerja dengan benar atau tidak, maka diperlukan sebuah pengujian terhadap LCD. Pengujian ini dilakukan dengan cara gerakan tangan atau anggota tubuh lainnya di depan sensor PIR dan untuk sensor suhu digunakan sebuah lampu dimmer untuk memberikan variasi suhu. Berikut ini hasil dari pengujian kerja LCD.

Tabel 4. Hasil Pengujian Kerja LCD

\begin{tabular}{|l|l|}
\hline Suhu $\left({ }^{\circ} \mathrm{C}\right)$ & Tampilan LCD \\
\hline$\leq 29$ & OFF \\
\hline 30 & SLOW \\
\hline 31 & SLOW \\
\hline 32 & SLOW \\
\hline 33 & SLOW \\
\hline 34 & SLOW \\
\hline 35 & MEDIUM \\
\hline 36 & MEDIUM \\
\hline 37 & MEDIUM \\
\hline 38 & MEDIUM \\
\hline 39 & MEDIUM \\
\hline$\geq 40$ & FAST \\
\hline
\end{tabular}

Dari hasil percobaan yang didapat pada table 4 , kondisi suhu selaras dengan keterangan yang ditampilkan di LCD. Tampilan di lcd juga berlangsung secara cepat seiring dengan perubahan nilai suhu. Hal ini disebabkan dalam pemrogramannya, lcd diberikan jeda waktu pembacaan suhu sebesar 1 detik agar lcd tidak terlalu cepat dalam menampilkan perubahan suhu. 


\subsection{Pengujian Putaran Motor DC (FAN)}

Motor DC (FAN) merupakan keluaran atau output yang digunakan dalam alat Kontrol Pendingin Ruangan (FAN) dengan logika fuzzy menggunakan ATmega 8535, LM 35 Dan PIR ini, domana motor DC (FAN) berfungsi sebagai pendingin ruangan. Pengujian ini dilakukan dengan cara gerakan tangan atau anggota tubuh lainnya didepan sensor PIR dan lampu dimmer yang akan memberikan masukan temperature (panas) ke LM 35. Dengan berbagai variasi suhu maka motor DC (FAN) akan berputar dan jika taka da gerakan manusia atau temperatur suhu $\leq$ $29^{\circ} \mathrm{C}$ maka motor akan berhenti berputar. Berikut ini hasil dari pengujian motor DC (FAN).

Tabel 5. Hasil Pengujian Motor DC (FAN).

\begin{tabular}{|l|l|l|l|}
\hline Gerakan Manusia & Suhu $\left({ }^{\circ} \mathrm{C}\right)$ & Putaran (RPM) & Tampilan LCD \\
\hline Tidak Ada & $\leq 29$ & 0 & OFF \\
\hline Ada & $\geq 30$ & 270 & SLOW \\
\hline Ada & $\geq 35$ & 512 & MEDIUM \\
\hline Ada & $\geq 40$ & 1120 & FAST \\
\hline
\end{tabular}

Dari hasil yang didapat pada tabel 5, kondisi led televisi dan buzzer selaras dengan cara kerja yang diberikan inputan yaitu sensor suhu LM 35 dan sensor gerak PIR.

\section{Analisis Rangkaian Secara Detail}

Rangkaian alat ini menggunakan tegangan atau catu daya DC (Direct Current) sebesar 9 Volt. Tahapan kerja alat ini dimulai dari pemberian sumber tegangan 9 Volt dimana tegangan ini kemudian diubah menjadi tegangan 5 Volt menggunakan regulator $L 7805 \mathrm{CV}$ yang sudah tersedia dalam sistem minimun ATmega 8535. Selanjutnya, tegangan 5 Volt digunakan sebagai sumber tegangan ATmega 8535, LM 35, PIR dan motor DC (FAN).

Sensor LM 35 dan sensor PIR berfungsi sebagai input ke mikrokontroler ATmega8535. Pada saat sensor PIR aktif maka sensor PIR akan mengaktifkan motor DC (FAN), atau menghentikan motor DC (FAN) jika sensor PIR tidak aktif. Sedangkan sensor LM 35 akan merubah suhu yang dideteksi menjadi tegangan sebagai inputan analog dan untuk selanjutnya akan diteruskan ke mikrokontroler mengkonversinya ke sinyal digital dengan bantuan ADC pada bagian port A.

Pada mikrokontroler ATmega 8535, sinyal clock dibangkitkan dari Xtal yang terhubung ke pin Xtal.1 \& Xtal.2. Kemudian, input dari sensor LM 35 \& sensor PIR diolah untuk ditentukan output yang sesuai dengan pemrograman bahasa $\mathrm{C}$ yang ditanamkan ke dalam mikrokontroler. Output ini selanjutnya dikirim ke port D.0 atau port D.1 atau port D.2. Untuk mengaktifkan motor DC (FAN) dengan logika fuzzy.

Mikrokontroler ATmega 8535 akan mengirimkan sinyal digital berlogika 0 atau 1 ke port D.0 atau port D.1 atau port D.2 yang difungsikan untuk mengaktifkan motor DC (FAN) dengan logika fuzzy, jika yang dikirim sinyal digital berlogika 1 maka motor DC (FAN) akan berputar dan jika yang dikirim sinyal digital berlogika 1 maka motor DC (FAN) akan berhenti.

Sedangkan keluaran mikrokontroler untuk LCD mengunakan port $\mathrm{C}$, berupa tampilan suhu dengan satuan " ${ }^{\circ} \mathrm{C}$ " pada baris pertama LCD dan tampilan putaran motor DC (FAN) pada baris kedua LCD.

\section{Kesimpulan}

Berdasarkan perancangan dan pengujian alat kontrol pending ruangan (FAN) dengan logika fuzzy menggunakan ATmega 8535, LM 35 dan PIR ini, maka dapat ditarik kesimpulan, beserta saran yang diperlukan untuk mengatasi kelemahan dari alat.

Berdasarkan hasil uji coba, menunjukkan bahwa alat ini bekerja sesuai dengan rancangannya, dimana jika tak ada gerakan manusia dan suhu $\leq 29^{\circ} \mathrm{C}$ maka motor DC (FAN) akan berhenti tampilan pada LCD "OFF", jika ada gerakan manusia dan suhu $\geq 30^{\circ} \mathrm{C}$ maka kecepatan motor DC (FAN) akan tampil pada LCD "SLOW”, jika ada gerakan manusia dan suhu 
$\geq 35^{\circ} \mathrm{C}$ maka kecepatan motor DC (FAN) akan tampil pada LCD "MEDIUM", jika ada gerakan manusia dan suhu $\geq 40{ }^{\circ} \mathrm{C}$ maka kecepatan motor DC (FAN) akan tampil pada LCD "FAST".

\section{Daftar Pustaka}

[1] Data Sheet Atmel Microcontroller ATmega 8535

[2] Data Sheet LCD 16x2 Paralel

[3] Data Sheet LM 35

[4] Data Sheet Motor DC (FAN)

[5] Data Sheet PIR Motion Detector HC-SR501

[6] Hidayat Taufik (2011), Rancang Bangun Alat Pendingin Ruangan Otomatis Berbasis Keberadaan Manusia Dan Suhu Ruangan. Jakarta :Universitas Gunadarma

[7] Indriani Anizar (2014), Pemanfaatan Sensor Suhu LM 35 Berbasis microcontroller ATmega 8535 pada Sisitem Pengontrolan Temperatur Air Laut Skala Kecil. Bengkulu : Universitas Bengkulu

[8] Iswanto (2011), Implementasi Mikrokontroller Sebagai Pengukur Suhu Delapan Ruangan. Yogyakarta : Universitas Muhammadiyah Yogyakarta

[9] Tarigan Pilipus (2013), Sistem Pengendali Pendingin Ruangan Menggunakan Fuzzy Logic Berbasis Mikrokontroler Atmega 8535. Medan : STMIK Budi Darma

[10] Maryanto Hendra (2010), Pembuatan Prototipe Pintu Otomatis Satu Arah Berbasis Mikrokontroler Atmega 8535 Menggunakan Double IR. Surakarta : Universitas Sebelas Maret 